\title{
Legal implications of range expansions in a terrestrial carnivore: the case of the golden jackal (Canis aureus) in Europe
}

\author{
Arie Trouwborst ${ }^{1} \cdot$ Miha Krofel $^{2} \cdot$ John D. C. Linnell ${ }^{3}$
}

Received: 27 February 2015/Revised: 2 June 2015/Accepted: 15 June 2015/

Published online: 27 June 2015

(C) The Author(s) 2015. This article is published with open access at Springerlink.com

\begin{abstract}
Due to global environmental changes, species are appearing more frequently in places where they have not previously occurred, and this trend is expected to continue. Such range expansions can create considerable challenges and confusion for management and policy, especially for species associated with conflicts and whose management is influenced by international legal frameworks. The golden jackal (Canis aureus) in Europe represents a good case study to address the questions related to management of naturally expanding species. We review the recent expansion of the golden jackal across the continent, and address several ensuing policy and legal questions that also have clear implications for other expanding species. To that end, we analyze the EU Habitats Directive and several other international legal instruments including the Convention on Biological Diversity and the Bern Convention on European Wildlife. We also review the status of the golden jackal under national legislation and highlight some of the management confusion due to recent range expansion and inadequate legal interpretation. Specific questions we address include in which cases an expanding species is to be considered an (invasive) alien species in countries where it did not formerly occur; what countries' conservation obligations are with respect to expanding species; what difference it makes for those obligations whether or not a species historically occurred in a country; what scope exists for lethal control of its populations; what the prospects are for transboundary cooperation at the population level; and what responses are required when colonizing species hybridise with other wildlife or domestic animals.
\end{abstract}

Communicated by Dirk Sven Schmeller.

Arie Trouwborst

a.trouwborst@tilburguniversity.edu

1 Department of European \& International Law, Tilburg Law School, Tilburg University, P.O. Box 90153, 5000 LE Tilburg, The Netherlands

2 Department of Forestry, Biotechnical Faculty, University of Ljubljana, Vecna Pot 83, 1001 Ljubljana, Slovenia

3 Norwegian Institute for Nature Research, Sluppen, P.O. Box 5685, 7485 Trondheim, Norway 
Keywords Golden jackal · Invasive alien species · Range expansion · EU Habitats Directive $\cdot$ International law

\section{Introduction}

In the face of global environmental change there is an expectation that many species will begin or continue shifting their distributions (Dormann 2007). Diverse mechanisms may drive these shifts, including climate change, habitat alteration, and management policy changes (Parmesan and Yohe 2003; Monzón et al. 2011). Irrespective of the underlying mechanism, species are increasingly appearing in places where they have not previously occurred. On an ecological level this leads to the creation of novel ecosystems (Hobbs et al. 2013). Additionally, these changes create challenges for management and policy, especially for species associated with conflicts (Redpath et al. 2013) and/or whose management is influenced by international legal instruments (Cliquet et al. 2009; Trouwborst 2013, 2014d). The golden jackal (Canis aureus) in Europe is one such species.

The European distribution of this medium-sized mammalian carnivore has traditionally been restricted to the continent's southeast. In the second half of the nineteenth century, the population started expanding in the southeastern Balkans and along the Danube basin as far as Hungary (Tóth et al. 2009). Since the mid-twentieth century, golden jackals have been expanding further northward and westward, appearing in areas and countries where they had not been recorded before. Jackals have been recently sighted as far west as Switzerland and as far north as Estonia. Continuation of this expansion appears likely (Arnold et al. 2012). It is still not certain what factors actually drive it, although we highlight some possible factors below.

For wildlife conservation and management authorities the arrival of golden jackals may generate various policy relevant questions for which the answers are not immediately obvious, and are influenced by international wildlife conservation legislation. Golden jackals have not yet attracted much research attention in Europe from either ecological or policy perspectives. This contrasts with the larger carnivores that have been subject to considerable attention in recent years from a diversity of disciplinary perspectives (Linnell et al. 2008; Chapron et al. 2014) and where the potential tensions between national objectives and international obligations have constituted a central focus (Trouwborst 2014c; Darpö and Epstein 2015).

Against this background, we aim to contribute to help clarify the implications of applicable international legal instruments for the conservation and management of golden jackals - and by implication other expanding species - in Europe. This includes addressing the following questions. Does the golden jackal constitute an (invasive) alien species in countries without prior records of its presence? What are the obligations regarding the conservation of golden jackals of states where the species presently occurs and of states being (re)colonized by the species? How much difference does it make for the answer to these questions whether jackals historically occurred in a country? What is the appropriate response if jackals hybridise with wolves (Canis lupus) or domestic dogs (Canis familiaris)? Besides these questions of international and European law, we also examine the golden jackal's status in national legislation. Before performing this legal analysis, we provide an updated assessment of the jackal's historic presence in Europe and its recent expansion. 


\section{Method}

The research for this paper combines a review of past and present golden jackal distribution with legal analysis. We used Arnold et al. (2012) as a basis regarding jackal distribution and expanded it to the Balkan region, which was mostly neglected in the former review (especially the countries of former Yugoslavia). We also reviewed recent literature concerning new golden jackal records, including grey literature and unpublished data. We were unable to obtain reliable information regarding exact distribution in Kosovo and Turkey. Therefore, for Kosovo we did not indicate data, although we are aware of jackal presence, and for Turkey we indicated approximate range in the northern part of the country according to Jhala and Moehlman (2004). Regarding the law, we primarily employed standard international and European legal research methodology (Trouwborst 2015a). This methodology consists, in particular, of the identification and analysis of relevant legal instruments and their provisions, including their interpretation according to the applicable rules from the international law of treaties as codified in the 1969 Convention on the Law of Treaties (Vienna Convention). According to these rules, treaty provisions must be interpreted according to the ordinary meaning of their terms in light of the treaty's objectives, while taking into account any 'subsequent agreements' or 'subsequent practice' by the parties (Vienna Convention, Article 31). As subsidiary sources, we used relevant guidance adopted by treaty parties or international institutions, international case law, and law literature. In addition, we performed a review of the current legal status of the golden jackal in the national legislation of European range countries. Whereas our review of jackal distribution encompasses Europe at large, including the Caucasus, our legal analysis focuses on Europe west of the Black Sea, which is where the most intricate legal questions arise.

\section{Results and discussion}

\section{Historic and current golden jackal distribution}

Paleontological records indicate that golden jackals were absent from Europe in the Pleistocene and most likely colonized the continent in the early Holocene (Sommer and Benecke 2005). Pre-sixteenth century records of golden jackal presence in Europe concern the Adriatic coast in Croatia (Vuletić-Vukasović 1908; Malez 1984), and the Mediterranean and Black sea regions of Greece and Bulgaria (Spassov 1989; Sommer and Benecke 2005; Markov 2012). The first confirmed records of golden jackal presence in the Pannonian (or Carpathian) Basin date from the nineteenth century (Tóth et al. 2009).

A notable expansion of the species started in the twentieth century, at first mainly along the eastern Adriatic coast (Kryštufek and Tvrtkovic 1990) and the mainland lowlands of southeastern and central Europe (Tóth et al. 2009). The first more pronounced wave of jackal expansion in central Europe occurred in the 1950s, with another wave following in the 1980s. Since then jackal numbers have steadily increased with occasional animals being documented to the north and the west far from the established populations.

There are presently records of reproducing golden jackal groups from most of southeastern Europe and parts of eastern and central Europe. Range countries include Albania, Armenia, Austria, Azerbaijan, Bosnia and Herzegovina, Bulgaria, Croatia, Georgia, Greece, Hungary, Italy, Kosovo, the Former Yugoslav Republic of Macedonia, Moldova, 
Montenegro, Romania, the Russian Federation, Serbia, Slovenia, Turkey and Ukraine. In addition, at least occasional presence of jackals-probably mostly vagrants for now-has been recorded in Belarus, the Czech Republic, Estonia, Germany, Latvia, Lithuania, Poland, Slovakia and Switzerland. (See Fig. 1 for details).

The factors driving or facilitating the golden jackal's expansion are still unclear, although land use changes apparently play a part (Šálek et al. 2014), and climate change may be implicated (Giannatos 2004; Arnold et al. 2012). Expansion may furthermore be easier where wolves, natural intra-guild predators of golden jackals, are uncommon or absent (Kryštufek and Tvrtkovič 1990; Giannatos 2004; Arnold et al. 2012).

\section{Applicable international and national legislation}

Golden jackals in Europe are covered, either specifically or indirectly, by multiple international legal instruments. These include the 1992 Convention on Biological Diversity (CBD), the 1979 Convention on the Conservation of European Wildlife and Natural Habitats (Bern Convention), and the 1992 European Union (EU) Directive 92/43 on the Conservation of Natural Habitats and of Wild Fauna and Flora (Habitats Directive). The

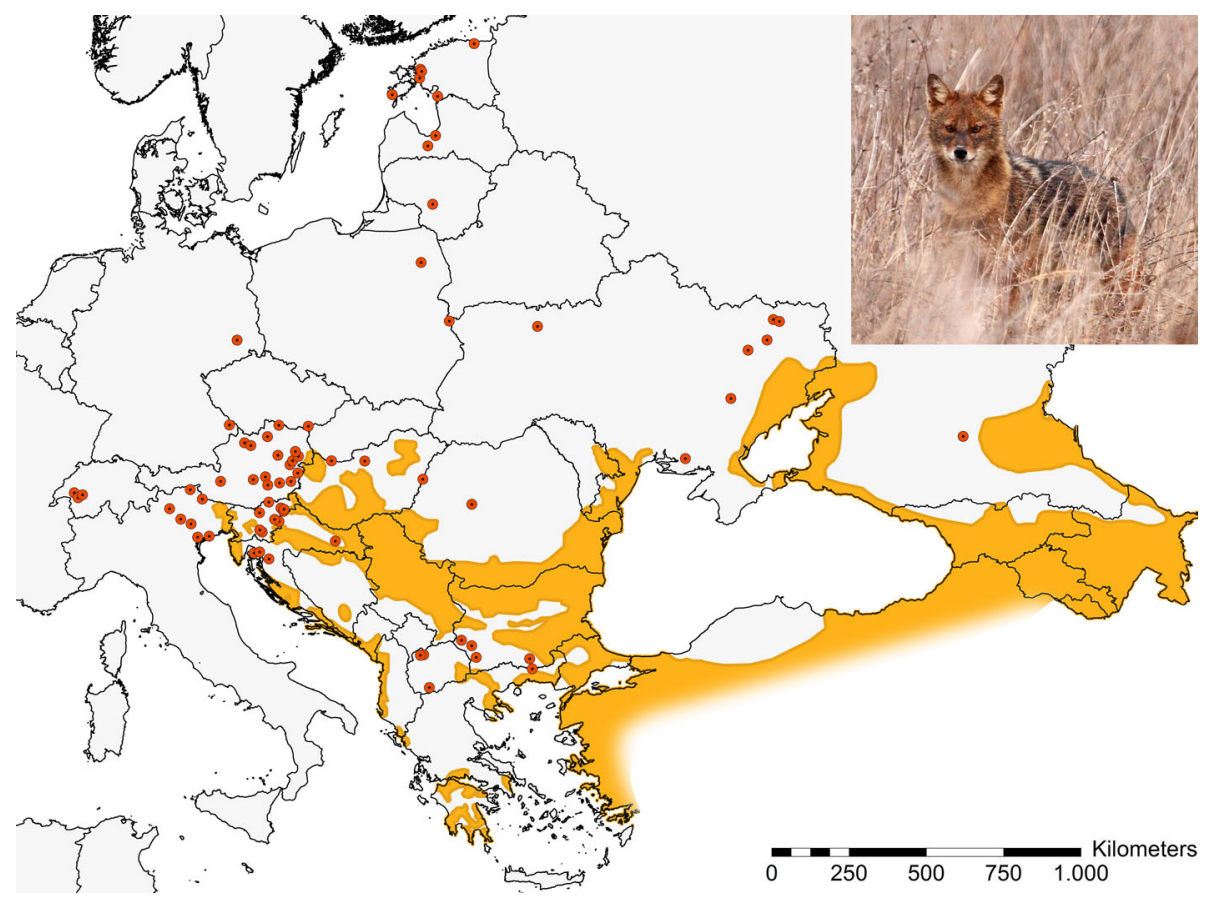

Fig. 1 Current distribution of golden jackal in Europe. Shaded areas represent areas of permanent presence of jackals and circles individual records. Data sources Arnold et al. (2012), Banea et al. (2012), Cazacu et al. (2014), Cirovic et al. (2014), Giannatos et al. (2005), Groff et al. (2014), Heltai et al. (2012), Heptner et al. (1998), Jhala and Moehlman (2004), KORA (2012), Koubek and Cerveny (2007), Krofel (2008a, b), Kryštufek et al. (1997), Markov (2012), Mihelič and Krofel (2012), Möckel (2000), Lapini et al. (2011), Levickaite (2015), LSM (2014), Roženko and Volokh (2010), Š́lek et al. (2014), Selanec et al. (2011), Stoyanov (2012), STV (2012), Szabo et al. (2007), Toom (2014), Trbojevic (2014), Weingarth et al. (2012), Žila (2014), M. Krofel, F. Álvares, W. Bogdanowicz and G. Giannatos, unpublished data. (Photo credit: (C) M. Krofel) 
aforementioned instruments not only provide a measure of guidance, but also concrete limits to the discretion available to national authorities when developing their responses to the arrival of golden jackals. Golden jackals in Europe are not listed under the 1973 Convention on International Trade in Endangered Species of Wild Fauna and Flora (CITES) or the 1979 Convention on the Conservation of Migratory Species of Wild Animals (CMS).

Of particular interest is the Habitats Directive, which is legally binding for the EU's 28 member states. The golden jackal is a 'species of Community interest' under the Directive,

Table 1 Legal status of golden jackal in Europe

\begin{tabular}{|c|c|c|c|}
\hline Country & National status & Habitats Directive & Bern Convention \\
\hline Albania & Fully protected & - & Basic regime \\
\hline Austria & Variable & Annex V & Basic regime \\
\hline Belarus & Unprotected & - & Basic regime \\
\hline Bosnia and Herzegovina & Hunted & - & Basic regime \\
\hline Bulgaria & Hunted & Annex V & Basic regime \\
\hline Croatia & Hunted & Annex V & Basic regime \\
\hline Czech Republic & Unprotected & Annex V & Basic regime \\
\hline Estonia & Unprotected & Annex V & Basic regime \\
\hline Germany & Fully protected & Annex V & Basic regime \\
\hline Greece & Unprotected & Annex V & Basic regime \\
\hline Hungary & Hunted & Annex V & Basic regime \\
\hline Italy & Fully protected & Annex V & Basic regime \\
\hline Kosovo & Hunted & - & - \\
\hline Latvia & Hunted & Annex V & Basic regime \\
\hline Lithuania & Hunted & Annex V & Basic regime \\
\hline FYR Macedonia & Fully protected & - & Basic regime \\
\hline Moldova & Unknown & - & Basic regime \\
\hline Montenegro & Hunted & - & Basic regime \\
\hline Poland & Fully protected & Annex V & Basic regime \\
\hline Romania & Hunted & Annex V & Basic regime \\
\hline Serbia & Hunted & - & Basic regime \\
\hline Slovakia & Hunted & Annex V & Basic regime \\
\hline Slovenia & Hunted & Annex V & Basic regime \\
\hline Switzerland & Fully protected & - & Basic regime \\
\hline Turkey & Variable & - & Basic regime \\
\hline Ukraine & Hunted & - & Basic regime \\
\hline
\end{tabular}

National legislation 'fully protected' indicates jackals may only be killed or captured in exceptional cases, 'hunted' indicates jackals may be killed in accordance with hunting legislation, 'unprotected' indicates killing jackals is not forbidden nor otherwise regulated or restricted, 'variable' indicates jackals' status varies from one part of the country to the next, 'unknown' indicates we were unable to verify legal status. Habitats Directive 'Annex V' indicates this regime applies to jackals, '-' indicates the Directive does not apply. Bern Convention 'basic regime' indicates basic provisions (and not Appendix II or III) apply to jackals, '-' indicates the Convention does not apply 
listed in its Annex V. When the Directive was adopted in 1992, the jackal's listing was only of relevance to the small population in Greece. Since then, the Directive's significance for the species has substantially increased. First, the Directive's geographic scope has expanded to cover more and more countries where jackal populations are recovering or attempting to establish themselves. For instance, Slovenia, Hungary, Slovakia, the Czech Republic, Poland and the Baltic states are among the countries gaining EU membership in 2004, with Bulgaria and Romania following suit in 2007, and Croatia as recently as 2013. Second, expanding golden jackals are increasingly finding their way into long established EU member states. In Austria and Italy, the first jackal sightings date from the late 1980s (Humer 2006; Lapini et al. 2009; Arnold et al. 2012). In Germany, the first jackal presence was recorded even more recently (Möckel 2000; Weingarth et al. 2012). The authorities in these countries in all probability, and quite understandably, were not thinking much of golden jackals when the Habitats Directive was drafted in the early 1990s, but will now need to consider the species. Similar situations arose following the dramatic expansion of the wolf (Trouwborst 2014b). Overall, golden jackals have been detected in fifteen EU member states (see Table 1). More may well follow, particularly countries bordering those already hosting jackals, for instance France.

With both the EU and the golden jackal progressively increasing the overlap in their ranges, an exploration and clarification of the implications of the Habitats Directive concerning this species is timely. Analysis of the Bern Convention is desirable as well, as golden jackals occur in many countries that are not EU member states, but are parties to the Convention.

A notable feature of the jackal's recent and potential future range expansion is that much of it involves apparent golden jackal terra incognita, lacking historic records of the species' former presence. This-together with its lesser legal protection status-makes the golden jackal's situation substantially different from that of the larger carnivores grey wolf, Eurasian lynx (Lynx lynx) and brown bear (Ursus arctos), whose ongoing European range expansions are actually comebacks (Chapron et al. 2014). The latter species have already been subject to a fair degree of analysis from a European and international legal perspective (Linnell et al. 2008; Darpö 2011; Linnell and Boitani 2012; Epstein 2013; Blanco 2013; Trouwborst 2010, 2014b, c, 2015b; Darpö and Epstein 2015). Whereas this large carnivore literature has certain relevance for our purposes, the jackals' distinct features highlighted above warrant further analysis.

At the national level, golden jackals' status under domestic law varies amongst the 26 countries west of the Black Sea where the species' presence has been confirmed (Table 1). In six countries, golden jackals are protected species in the sense that their killing or capturing is in principle not allowed. This is obviously the case where jackals have been expressly accorded a protected status, but protection may also result in the absence of explicit designation in domestic legal systems where killing and capturing wild animals is only allowed for species expressly mentioned in (hunting) legislation. In fourteen countries, golden jackals may be hunted in accordance with national hunting legislation, which in many cases includes a defined hunting season (e.g. Montenegro, Romania, Slovakia, Slovenia). In a few countries, killing or capturing golden jackals is not forbidden nor otherwise regulated. In Austria and Turkey, the legal status of the species varies between administrative units.

\section{Golden jackal: an alien species?}

The Habitats Directive, Bern Convention and CBD aim to contribute to conserving native wildlife, and all three call for measures to prevent the (deliberate) introduction of, and/or to 
control or eradicate, invasive alien species (CBD Article 8(h); Bern Convention Article 11(2)(b); Habitats Directive Article 22(b)). Furthermore, dedicated EU legislation dealing with this issue entered into force on 1 January 2015 (Regulation 1143/2014 on the Prevention and Spread of Invasive Alien Species). For our purposes it is therefore important to know what is understood by 'alien species' as opposed to native wildlife.

According to a definition adopted by the CBD Conference of the Parties (COP), an 'alien species' is a species 'introduced outside its natural past or present distribution' (CBD COP Decision VI/23, 2002). The same Decision defines 'introduction' as the 'movement by human agency, indirect or direct, of an alien species outside of its natural range (past or present)'. The element of introduction by man is also featured in the definition of 'alien species' employed in EU Regulation 1143/2014: 'any live specimen of a species, subspecies or lower taxon of animals... introduced outside its natural range' (Article 3(1)). Under both instruments, whether an alien species is also considered 'invasive' depends on whether it poses a threat to native biodiversity. A classic European example of an 'invasive alien species' as defined above is the ruddy duck (Oxyura jamaicensis), introduced from America, posing a major threat to the indigenous white-headed duck (Oxyura leucocephala) (BirdLife International 2012).

These definitions of 'alien species' thus only include species that have been introduced by man, and exclude species which spread beyond their previously known range on their own. Thus, the fact that a species cannot be proven to have historically occurred in a recently colonized territory does not make it an 'alien species'. A clear example is the European expansion of the Eurasian collared dove (Streptopelia decaocto) over the last century, which does not qualify the bird as 'alien' in the newly occupied territories (RochaCamarero and De Trucios 2002).

An interesting parallel may be drawn with range shifts that are apparently driven by climate change. Of interest in this respect is a Recommendation adopted by the Standing Committee (the 'COP' equivalent) of the Bern Convention. 'Worried that native species moving to neighbouring areas may be considered as alien due to the fact that climate change is the result of human action and that such species may be unnecessarily controlled', the Committee interprets the term 'alien species' as 'not including native species naturally extending their range in response to climate change' (Recommendation 142 (2009)). Likewise, the new EU Regulation 'applies to all invasive alien species', and specifically does not apply to 'species changing their natural range without human intervention, in response to changing ecological conditions and climate change' (Article 2(1)(2)). The COP of the CMS has also adopted interpretations of Convention provisions geared towards welcoming rather than deterring species naturally changing their distribution in apparent response to climate change (CMS COP Resolutions 10.19 (2011) and 11.26 (2014); Trouwborst 2012).

As noted above, subfossil records denote golden jackal presence in parts of Europe for thousands of years (Sommer and Benecke 2005). At any rate, as the recent and ongoing range expansion of the golden jackal in Europe is apparently not the result of active introduction by humans, it should be classified in the same category as the collared dove, and not that of the ruddy duck.

\section{Habitats Directive Annex V}

The golden jackal is only listed in Habitats Directive Annex V which covers 'Animal and plant species of community interest whose taking in the wild and exploitation may be subject to management measures'. Given the jackal's rarity within the EU when the 
Directive was adopted, it is striking that the flexible Annex V regime was chosen instead of strict protection under Annex IV.

No exceptions regarding Annex V status of golden jackals apply for any EU member state or part thereof-in contrast with, e.g., the diverse legal status of wolves across the EU. The Annex IV regime requiring strict protection therefore does not apply to jackals anywhere in the EU. As the golden jackal is not listed in Annex II either, no obligations exist regarding the designation and protection of Special Areas of Conservation for jackals as part of the Natura 2000 network.

Whereas Annex V status evidently applies in traditional jackal countries like Greece, Bulgaria, Croatia and Hungary, this is at first sight perhaps less obvious regarding EU member states which, according to the available evidence, are outside the golden jackal's historic range or which did not contain jackals when they became bound by the Habitats Directive. From a legal perspective, however, there is little in the Directive to suggest the existence of any limitations in this regard. The Directive aims for wildlife conservation 'in the European territory of the Member States' (Article 2(1)). Measures taken pursuant to the Directive 'shall be designed to maintain or restore, at favourable conservation status,... species of wild fauna... of Community interest' (Article 2(2)). The golden jackal is such a species, and more specific obligations follow from its Annex V listing, as discussed below.

A meaningful clue regarding the question whether 'new' jackal member states are also expected to meet these Annex V obligations relates to the term 'natural range', which is one of the elements of the concept of 'conservation status' as defined in the Directive (Article 1(i)). Notably, the Directive does not expressly limit the scope of application of the Annex $\mathrm{V}$ regime to the natural ranges of species involved. Conversely, providing strict protection to Annex IV animals is expressly required only 'in their natural range' (Article 12). An analogous limitation concerning Annex V may, however, be assumed to apply, bearing in mind inter alia the Directive's overarching objective of conserving native European wildlife. For instance, regarding Annex V species Article 15 requires the prohibition of all indiscriminate means of capture or killing that are 'capable of causing local disappearance of, or serious disturbance to, populations of such species'. Whereas Article 15 does not specify that this prohibition is only required within the species' natural range, it would obviously be nonsensical, and contrary to the Directive's objectives, to consider this requirement applicable in a hypothetical scenario in which golden jackals have been illegally released into the wild in a place the animals could not possibly have reached on their own, like the UK or Ireland.

It is beyond doubt that in the context of the Habitats Directive the contours of a species' 'natural range' are not to be determined top-down by member states' authorities but bottom-up by the animals themselves. This is manifested inter alia in guidance provided by the European Commission, which employs a flexible and pragmatic understanding of the concept. It is useful to indicate first what is, according to the Commission, not to be regarded as a species' natural range:

'...individuals or feral populations of an animal species introduced deliberately or accidentally by man to locations where they have never occurred naturally, or where they would not have spread to naturally in the foreseeable future, should be considered to be outside their natural range and consequently not covered by the Directive. Vagrant or occasional occurrences would also not be considered as part of the natural range' (European Commission 2007).

Conversely, when a species 'has been reintroduced into its former natural range (in accordance with the rules in Article 22 of the Habitats Directive)' and when a species 
'spreads on its own to a new area/territory', then 'this territory has to be considered part of the natural range' (European Commission 2007). Whether the species formerly occurred in the area is evidently not deemed a prerequisite in the latter scenario.

Similarly, for the purposes of member states' reporting duties under Article 17 of the Directive, the European Commission recommends that 'occasional records' beyond the usual area of distribution should not influence the shape and size of a species' range (Evans and Arvela 2011). Contrariwise, 'outliers' should be counted as part of a species' range 'if they represent regular or stable occurrences' (Evans and Arvela 2011).

Most of the Commission's reasoning regarding the interpretation of the 'natural range' concept would appear to be compatible with the provisions of the Habitats Directive read in light of its overall purpose. However, the 2007 guidance document's position regarding vagrants and 'occasional occurrences' may well pose an exception in this regard (European Commission 2007). The document appears to imply that pioneering individuals located beyond a species' established distribution are to be considered outside the 'natural range' and therefore not covered by the Directive. The position that such animals are entirely unprotected by the Directive seems to be at odds with the Directive's aims. In particular, the consistent elimination of such individuals which would be permitted according to this position could clearly impede a species' natural range expansion-which would be contrary to the aims of the Directive and the position taken on naturally expanding populations under other international legal instruments (see "Golden jackal: an alien species?" section). The golden jackal is a case in point. Recent expansion patterns suggest that areas at first colonized only by vagrants and having occasional occurrence usually become the scene of formation of territorial groups in the following years or decades (Krofel 2009). Therefore, for any area with occasional occurrence of jackals there seems to be a high probability-if nature is left to run its course-that the natural range will be expanded to this area in the foreseeable future.

Overall, the correct conclusion would appear to be that all EU member states where golden jackals occur, including countries where jackals have recently arrived without human assistance, are bound by the Directive's obligations regarding Annex V species. That legal regime will consequently also apply to golden jackals spreading by themselves to countries like Estonia, Germany or France.

Some of the ambiguity may be illustrated with reference to the situation in the Baltic states. In Estonia and Latvia, jackals of unknown origin have been recorded since 2011 and were believed to have arrived there through natural expansion (Banea 2013; Toom 2014). However, the Estonian and Latvian governments regarded the species as alien and allowed unlimited lethal removal with the aim of eradicating the species, which resulted in several animals being shot in 2013 and 2014 (ERR 2013; LSM 2014; Toom 2014). In February 2015, a golden jackal was shot in Lithuania, where it was subsequently also regarded by the authorities as an alien species to be eradicated (Levickaite 2015; V. Balys, pers. com.). We consider three scenarios in this context, with their associated legal consequences.

Scenario (A): The jackals were introduced by man and the Baltic states must be considered as outside their 'natural range'. In this scenario, the Baltic jackals originate from a deliberate or accidental release by humans, and qualify as 'alien'. The Annex V regime does not apply, and the animals are eligible for removal. In case the jackals also qualify as 'invasive', i.e. harmful to native biodiversity, eradication may indeed be called for according to the obligations cited at the outset of the "Golden jackal: an alien species?" section. That this is the scenario believed to exist by the government authorities involved is aptly illustrated through the reference by an Estonian official to 'several regulations on the international level for the event of discovering a new foreign species population' according 
to which 'the species should be eradicated as quickly as possible before it becomes a complicated, expensive or impossible process' (K. Lotman, as quoted in ERR 2013).

Scenario (B): The jackals were introduced by man, but the Baltic states must be considered as inside their 'natural range'. The Commission's guidance document cited above appears to offer scope for considering animals that were introduced by man to locations they would themselves likely 'have spread to naturally in the foreseeable future' as being inside their 'natural range' for the purposes of the Directive. Insofar as this reading of the Directive is correct, and assuming the natural colonization of the Baltic states by golden jackals is a real prospect - and the available data indicate that it is - then golden jackals in Estonia, Latvia and Lithuania may be considered subject to the Annex V regime even if it is established or suspected that they were released by humans. A policy of eradication is incompatible with this regime (see also "Lethal control, hunting and FCS" section). It should in any event be borne in mind that generally speaking, in the absence of relevant case law of the Court of Justice of the EU (CJEU), the text of the Habitats Directive leaves room for debate regarding the legal status of animals which belong to listed species but result from unauthorized introductions (Pillai and Heptinstall 2013).

Scenario $(C)$ : The jackals reached the Baltic states by themselves. In this scenario, the authorities are apparently bound by the regime of Annex V of the Habitats Directive with regard to the golden jackals within their respective territories.

This set of scenarios begs the question as to the onus of proof when-as in the case of the Baltic jackals - doubt or disagreement arises as to whether the presence of particular animals is the result of human introduction or natural expansion. Unsurprisingly, member states are expected to act on the basis of the best data available when implementing their obligations under the Habitats Directive. If the available information is ambiguous and supports neither scenario over the other, member states must act in accordance with the precautionary principle (CJEU 7 September 2004, Case C-127/02), opting for the course of action that is most likely to secure the Directive's conservation objectives-in dubio pro natura-and avoiding irreversible harm. The present instance is complicated by the fact that scenarios (A) and (C) have two potentially conflicting biodiversity conservation objectives associated with them, namely control of a potentially invasive alien species in the introduction scenario and golden jackal conservation in the natural colonization scenario. The criterion that irreversible harm is to be avoided may serve to break the tie in situations such as these, although in the Baltic jackal case it may arguably be constructed in support both of not culling the jackals until more is known regarding their origins as well as in support of culling them in order to remove the incipient population before it becomes impossible to do so.

At any rate, on the facts of the Baltic situation it would appear that natural expansion is the most plausible explanation, given what we know about the jackals' recent expansion patterns and dispersal capabilities, including recent records from northwestern Ukraine, southwestern Belarus and northeastern Poland (see Fig. 1), and in the absence of concrete evidence pointing in the direction of an introduction. The prevailing argument would thus appear to be that the Estonian, Latvian and Lithuanian authorities should treat the jackals within their respective boundaries as being subject to the regime of Annex V, although we believe the complexity of the legal situation and the lack of certainty regarding the Baltic jackals' origins prevent a categorical conclusion.

Unlike the Annex IV regime, which requires national legislation strictly prohibiting the killing and capturing of individual animals subject to limited exception (derogation) possibilities (Articles 12 and 16), Annex V status leaves competent authorities with significantly more leeway regarding the tools they may use to conserve and manage animal 
populations. Article 14 of the Habitats Directive enumerates measures that may be applied by member states to regulate the exploitation of Annex V populations, e.g. closed seasons and license systems. Yet, these are presented as options rather than obligations. The discretionary room for member states regarding golden jackals is not unlimited, however. First and foremost, they are clearly bound by a general obligation to ensure a 'favourable conservation status' (FCS) (European Commission 2007; García Ureta 2010; López-Precioso 2012; Trouwborst 2014b). Second, Article 11 as interpreted by the CJEU requires member states to guarantee that surveillance of golden jackals' conservation status 'is undertaken systematically and on a permanent basis' (CJEU 20 October 2005, Case C-6/ 04). Third, Article 15 of the Directive outlaws the use of certain means and modes of capture and killing, including poison(ed baits), (semi-) automatic weapons and all other 'indiscriminate means capable of causing local disappearance of, or serious disturbance to, populations.' Exceptions to allow such means may only be made when the three conditions set out in Article 16 are met, namely that (i) 'there is no satisfactory alternative', (ii) the exception is 'not detrimental to the maintenance of the populations of the species concerned at a favourable conservation status', and (iii) the exception is made for one of several defined purposes, including inter alia research purposes and the prevention of 'serious damage' to livestock.

\section{The Bern Convention}

The parties to this pan-European wildlife conservation treaty include virtually all European states, including all 28 EU member states, and the EU itself. An exploration of the Convention's significance is called for in particular with respect to contracting parties where golden jackals occur but where the Habitats Directive does not apply, e.g. Serbia, Switzerland, Turkey and Ukraine (see also Table 1). The Convention contains specific provisions concerning the generic protection of species listed in its Appendices II and III, and the conservation of their habitats. These do not apply in the current context, however, as the golden jackal is not presently included in either Appendix. Nevertheless, several Convention provisions address the conservation of non-listed species.

The Bern Convention aims to "conserve wild flora and fauna and their natural habitats, especially those species and habitats whose conservation requires the co-operation of several States, and to promote such co-operation' (Article 1). To achieve this broad objective, Article 2 stipulates regarding all wildlife that parties 'shall take requisite measures to maintain the population of wild flora and fauna at, or adapt it to, a level which corresponds in particular to ecological, scientific and cultural requirements, while taking account of economic and recreational requirements.' This 'level' is not defined in more detail. Much will thus depend on the circumstances and the positions taken by parties in each case, although it appears safe to assume that species should at a minimum be conserved with a view to avoiding their inclusion in the IUCN Red List at a level worse than 'Least Concern' (Bowman et al. 2010; Fleurke and Trouwborst 2014). Regarding habitat protection, the Convention stipulates that for all 'wild flora and fauna species'-therefore also for golden jackals where they occur-each party 'shall take appropriate and necessary legislative and administrative measures to ensure the conservation' of their habitats (Article 4(1)). The parties 'in their planning and development policies shall have regard to the conservation requirements' of the areas thus protected, 'so as to avoid or minimise as far as possible any deterioration of such areas' (Article 4(2)).

The aforementioned Standing Committee is the Convention's main decision-making body. Its broad powers include considering amendments and recommending particular 
actions to ensure the Convention's effective application, either generally or regarding specific species/parties. Notably, the Committee has already addressed issues concerning non-listed species, e.g. striped hyena (Hyaena hyaena) in Azerbaijan (Recommendation No. 148 (2010)). Thus, even if golden jackals are not listed, it is conceivable for the Standing Committee in future to adopt specific guidance concerning their conservation.

\section{Lethal control, hunting and FCS}

From an EU legal perspective, lethal control of Annex V animals like golden jackals is a more straightforward management option than for wildlife populations to which Annex IV applies, and hunting can be allowed as long as a FCS is secured and regular systematic monitoring is implemented. As a guidance document of the European Commission on strict protection sums it up, 'species covered by Annex V can be exploited, although such exploitation should not jeopardise the objective of maintaining their favourable conservation status in any way' (European Commission 2007). It is important to note in the current context that, apparently, the Habitats Directive does not allow member states where golden jackals are spontaneously arriving and attempting to establish themselves, to pursue the eradication of the species.

Some interpretation questions regarding the key concept of FCS are still extant. A particularly important one concerns the level(s) at which FCS is to be assessed and achieved. It is unclear whether FCS for wide-ranging (large) carnivore species is to be ensured at the level of the transboundary population involved or (also) at the national level. As this matter was already analyzed in some detail by Trouwborst (2014b), it suffices to highlight the question as such and to recall that arguments exist in favour of either position in this presently unresolved matter.

Another question is what scope exists for the removal of golden jackals from the wild when FCS has not yet been achieved. This question is pertinent especially when assuming that a FCS for golden jackals must be ensured by each member state at the national level, and particularly regarding the early stages of jackal colonization in countries on the fringes of the species' expanding range. The CJEU has already addressed this issue with regard to strictly protected species from Annex $I V$. In a case concerning wolves in Finland, the Court held that derogations from strict protection affecting animals from populations that are not at a FCS may still be permissible "where it is duly established that they are not such as to worsen the unfavourable conservation status of those populations or to prevent their restoration at a favourable conservation status' (CJEU 14 June 2007, Case C-342/05). The judgment expressly endorses the interpretation from a Commission guidance document that the elimination of one or a few animals can be neutral in the sense that the prospect of a favourable status is not impaired (European Commission 2007). Nonetheless, according to the same Commission guidance such a flexible approach is possible only when the ultimate achievement and maintenance of a FCS is warranted through a "clear and welldeveloped framework of species conservation measures' consisting of 'appropriate, effective and verifiable' measures (European Commission 2007). Species protection plans are accorded a significant role in this connection. Such plans may, in the Commission's view, be essential in demonstrating the compatibility of derogations with the Directive (European Commission 2007). The firmer the plan-i.e., the more likely it will ensure a FCS - the more room for the granting of derogations where these are deemed desirable. Similarly, the Guidelines for Population Level Management Plans for Large Carnivores in Europe ('Carnivore Guidelines') which were endorsed by the European Commission in 2008 , state that at unfavourable conservation status, limited exemptions from the strict 
protection of large carnivores can be acceptable, but 'the arguments must be very strong' (Linnell et al. 2008). According to the Carnivore Guidelines, the latter condition is really only fulfilled when 'a detailed conservation/management plan' guarantees that the removal of one or more animals, in combination with other derogations, does not adversely affect conservation status.

Regarding Annex $V$ species like the golden jackal, more flexibility for management authorities can be expected, if anything. However, nothing in the Directive suggests that warranting a FCS as such is more important for some species or populations (those in Annex IV) than for others (those in Annex V). The difference between the two categories is one of means, not of objectives. Thus, just like for Annex IV species, the burden of demonstrating that golden jackals are on their way to attaining a FCS, and that the management of the species is compatible with this target, must be assumed to rest firmly on the member state involved. Notably, implementation of the recommendations on lethal control and hunting of large carnivores contained in the Carnivore Guidelines (Linnell et al. 2008) would seem to go a long way towards meeting this burden, also for golden jackal. Considering the above, it is far from evident that all EU member states where jackals currently occur are complying with their obligations under the Habitats Directive. To take a conspicuous example, in Greece golden jackals appear to be drifting away from a FCS rather than approaching it (Giannatos et al. 2005; Arnold et al. 2012). This makes it difficult to justify the fact that Greek legislation does not impede or control the killing of jackals.

Non-EU member states appear to have more flexibility regarding lethal control and hunting of golden jackals, even if this is not unfettered in view of the general obligations imposed by the Bern Convention.

\section{Transboundary cooperation}

The specific ecological properties (large spatial requirements and the chronic conflicts they cause with human interests) of the European large carnivores-brown bear, wolf, Eurasian lynx and wolverine (Gulo gulo) - have motivated the development of the aforementioned Carnivore Guidelines (Linnell et al. 2008). One of the main elements of these guidelines is the recommendation that member states increase their efforts to coordinate their conservation actions across jurisdictional borders (both intra- and inter-national), so as to adjust these actions to the level of large carnivore (sub)populations rather than the level of any administrative unit (Linnell et al. 2008; Blanco 2013; Epstein 2013; Trouwborst 2015b). According to the European Commission, the Carnivore Guidelines 'represent best practice for the management of large carnivore populations' (European Commission 2008). Furthermore, the issues at hand must be viewed in light of Article 11 of the Bern Convention, requiring parties to 'cooperate whenever appropriate and in particular where this would enhance the effectiveness of measures taken under other articles of this Convention' (Trouwborst 2014b). The attention of Bern Convention parties has also been drawn specifically to the Carnivore Guidelines (Standing Committee Recommendation No. 137 (2008)), and the Standing Committee has on several other occasions underlined the need for governments to cooperate on the conservation of transboundary large carnivore populations (e.g. Recommendations Nos. 115 (2005) and 148 (2010)).

The question arises to what extent these considerations apply to golden jackals. An important issue in this regard concerns whether golden jackals should be considered as a functional part of the large carnivore guild or the smaller species within the meso-predator guild. Ecologically speaking they occupy an intermediate position between these two groups. The fact that they have smaller home ranges and can occur at higher densities than 
any of the larger carnivores implies that they are less dependent on transboundary cooperation to achieve population viability. Furthermore, they are currently associated with fewer of the conflicts that characterize the larger species and which motivate the need for specific management approaches. However, the rapid spread of golden jackals across Europe and the apparent ability of dispersers to appear far from established breeding populations imply that states may well benefit from exchanging information and experience, and from spatially coordinating their conservation and management actions. An important consideration regarding such coordination is the existence of considerable differences concerning golden jackals' status in national law between countries sharing jackal populations ("Applicable international and national legislation" section; Table 1).

\section{Hybridization}

In Europe, golden jackals may crossbreed with domestic dogs and with wolves (Leonard et al. 2014; Moura et al. 2014). From the perspective of international and EU wildlife law, a clear distinction is to be drawn between anthropogenic and natural hybridization (Allendorf et al. 2001; Genovart 2009).

Clearly, hybridization with dogs constitutes anthropogenic hybridization. Such hybridization may, in principle, adversely affect the conservation status of golden jackals. Taking preventive measures, in particular minimizing the number of free-ranging dogs, and mitigation measures, in particular the detection and removal of jackal-dog hybrids, is evidently in line with obligations under both the Habitats Directive and the Bern Convention (Trouwborst 2014a). This is also the course of action set out in a recently adopted Standing Committee Recommendation concerning the measures to be taken by Bern Convention parties to address wolf-dog hybridization (Recommendation No. 173 (2014)). It would appear, in this regard, that the best practice recommendations provided in the Carnivore Guidelines on wolf-dog hybridization may-mutatis mutandis-be applied to jackal-dog hybridization (Linnell et al. 2008). Another apparently appropriate preventive measure is ensuring the stability of golden jackal social groups. As jackals are monogamous species, hybridization with dogs is probably unlikely as long as both of a group's dominant pair survive (see the similar discussion regarding hybridization with wolves below). There is therefore a distinct possibility that population perturbation, e.g. through widespread hunting, may increase the risks of hybridization. However, it is important to underline that the current level of scientific knowledge of golden jackal demography and social organization in Europe is low.

Hybridization between golden jackals and wolves, already reported in Bulgaria (Moura et al. 2014), may at first sight seem to be a different matter, as it does not involve domesticated or alien species. As such, it would seem to constitute an instance of natural hybridization. Insofar as this is indeed the case, measures to counter jackal-wolf hybridization would, in principle, not be called for under international or EU wildlife law (Trouwborst 2014a). There is reason to believe, however, that hybridization between golden jackals and wolves does not represent an altogether 'natural' process. It has been demonstrated that the probability of hybridization among canids is affected by the stability of social groups. [On wolf culling and hybridization with jackals (and also dogs) see Moura et al. (2014); for effects of social group disruption on hybridization among canids see Grant et al. (2005), Rutledge et al. (2010, 2012) and Bohling and Waits (2015)]. Survival of breeding individuals is the main factor affecting pack stability, and is under strong influence of anthropogenic mortality. When human-induced mortality, whether through authorized lethal control or illegal killing, causes breeding individuals to die in 
considerably higher proportion compared to natural mortality, this increases the prospects of hybridization between wolves and golden jackals. Such hybridization then lands in the anthropogenic category rather than the natural one. From a legal perspective, action may then be called for to curb human-induced mortality in order to ensure an adequate survival rate of breeding individuals and thus prevent (anthropogenic) jackal-wolf as well as jackaldog hybridization.

\section{Conclusions}

From both a conservation and a legal perspective, golden jackals in Europe have been a neglected species, subject to many misconceptions. Our analysis shows that the notion of golden jackals being an alien species in most of Europe is one such misconception. It also shows that current international legal obligations limit the freedom of countries to decide how they wish to deal with newly arriving golden jackals. In EU member states in particular, the Habitats Directive imposes distinct limitations on national policy and management options regarding the golden jackal, including in scenarios where jackals are spreading to areas without historic records of their presence. As more and more species can be expected to expand beyond their historic ranges under influence of global environmental changes, our findings have implications also beyond the case of the golden jackal.

Acknowledgments The authors gratefully acknowledge comments and/or information provided by Francisco Álvares, Janosch Arnold, Vaidas Balys, Ovidiu Banea, Wieslaw Bogdanowicz, Özgün Emre Can, Ellen Frank, Georgios Giannatos, Gjorge Ivanov, Peep Männil, Eric Marboutin, Janis Ozolins, Martin Šálek, Marina Shkvyria, Vadim Sidorovic, Aleksander Trajce, Fridolin Zimmermann and the anonymous reviewers. AT was funded by the Netherlands Organization for Scientific Research, as part of the project 'Ius Carnivoris' (Project no. 452-13-014). MK was funded by the Slovenian Research Agency (Grant no. P4-0059). JDCL was funded by the Research Council of Norway and the Norwegian Environmental Agency.

Conflict of interest The authors declare that they have no conflicts of interests.

Open Access This article is distributed under the terms of the Creative Commons Attribution 4.0 International License (http://creativecommons.org/licenses/by/4.0/), which permits unrestricted use, distribution, and reproduction in any medium, provided you give appropriate credit to the original author(s) and the source, provide a link to the Creative Commons license, and indicate if changes were made.

\section{References}

Allendorf FW, Leary RF, Spruell P, Wenburg JK (2001) The problems with hybrids: setting conservation guidelines. Trends Ecol Evol 16:613-622

Arnold J, Humer A, Heltai M, Murariu D, Spassov N, Hackländer K (2012) Current status and distribution of golden jackals Canis aureus in Europe. Mamm Rev 42:1-11

Banea O (2013) Jackals in West Estonia. GOJAGE blog, 1 March 2013. http://goldenjackalaround.blogspot. com/2013/03/golden-jackal-survey-in-w-estonia.html. Accessed 13 Jan 2015

Banea OC, Krofel M, Červinka J, Gargarea P, Szabó L (2012) New records, first estimates of densities and questions of applied ecology for jackals in Danube Delta Biosphere Reserve and hunting terrains from Romania. Acta Zoologica Bulgarica 64:353-366

BirdLife International (2012) Oxyura leucocephala. The IUCN Red List of Threatened Species (Version 2014.3). http://www.iucnredlist.org. Accessed 18 Feb 2015

Blanco JC (2013) Towards a population level approach for the management of large carnivores in Europe: challenges and opportunities. European Commission, Brussels

Bohling JH, Waits LP (2015) Factors influencing red wolf-coyote hybridization in eastern North Carolina, USA. Biol Conserv 184:108-116

Bowman M, Davies P, Redgwell C (2010) Lyster's international wildlife law, 2nd edn. Cambridge University Press, Cambridge 
Cazacu C, Adamescu MC, Ionescu O, Inonescu G, Jurj R, Popa M, Cazacu R, Cotovelea A (2014) Mapping trends of large and medium size carnivores of conservation interest in Romania. Ann Forest Res 57:97-107

Chapron G, Kaczensky P, Linnell JDC, von Arx M, Huber D, Andrén H, López-Bao JV, Adamec M, Álvares F, Anders O, Balčiauskas L, Balys V, Bedő P, Bego F, Blanco JC, Breitenmoser U, Brøseth H, Bufka L, Bunikyte R, Ciucci P, Dutsov A, Engleder T, Fuxjäger C, Groff C, Holmala K, Hoxha B, Iliopoulos Y, Ionescu O, Jeremić J, Jerina K, Kluth G, Knauer F, Kojola I, Kos I, Krofel M, Kubala J, Kunovac S, Kusak J, Kutal M, Liberg O, Majić A, Männil P, Manz R, Marboutin E, Marucco F, Melovski D, Mersini K, Mertzanis Y, Mysłajek RW, Nowak S, Odden J, Ozolins J, Palomero G, Paunović M, Persson J, Potočnik H, Quenette P-Y, Rauer G, Reinhardt I, Rigg R, Ryser A, Salvatori V, Skrbinšek T, Stojanov A, Swenson JE, Szemethy L, Trajçe A, Tsingarska-Sedefcheva E, Váňa M, Veeroja R, Wabakken P, Wölfl M, Wölfl S, Zimmermann F, Zlatanova D, Boitani L (2014) Recovery of large carnivores in Europe's modern human-dominated landscapes. Science 346:1517-1519

Ćirović D, Penezić A, Milenković M, Paunović M (2014) Winter diet composition of the golden jackal (Canis aureus L., 1758) in Serbia. Mamm Biol 79:132-137

Cliquet A, Backes C, Harris J, Howsam P (2009) Adaptation to climate change: legal challenges for protected areas. Utrecht Law Rev 5:158-175

Darpö J (2011) Brussels advocates Swedish grey wolves: on the encounter between species protection according to Union law and the Swedish wolf policy. SIEPS Eur Policy Anal 2011(8):1-19

Darpö J, Epstein Y (2015) Under fire from all directions: Swedish wolf management hunting scrutinized by Brussels and at home. In: Born C, Cliquet A, Schoukens H, Misonne D, Van Hoorick G (eds) The habitats directive in its EU environmental law context: European nature's best hope?. Routledge, London, pp 348-372

Dormann CF (2007) Promising the future? Global change projections of species distributions. Basic Appl Ecol 8:387-397

Epstein Y (2013) Population based species management across legal boundaries: the Bern Convention, Habitats Directive, and the gray wolf in Scandinavia. Georgetown Int Environ Law Rev 25:549-597

ERR (2013) Jackals, a non-native species, to be eradicated. ERR News. http://news.err.ee/v/environment/ cc5a4ea7-6051-4f8a-bc9e-fe271885992d. Accessed 13 Jan 2015

European Commission (2007) Guidance document on the strict protection of animal species of Community interest under the Habitats Directive 92/43/EEC. European Commission, Brussels

European Commission (2008) Note to the guidelines for population level management plans for large carnivores. European Commission, Brussels

Evans D, Arvela M (2011) Assessment and reporting under article 17 of the Habitats Directive: explanatory notes and guidelines for the period 2007-2012. European Commission, Brussels

Fleurke FM, Trouwborst A (2014) European regional approaches to the transboundary conservation of biodiversity: the Bern Convention and the EU Birds and Habitats Directives. In: Kotze L, Marauhn T (eds) Transboundary governance of biodiversity. Martinus Nijhoff Publishers, Leiden and Boston, pp 128-162

García Ureta A (2010) Derecho Europeo de la biodiversidad: aves silvestres, hábitats y especies de flora y fauna. Iustel, Madrid

Genovart M (2009) Natural hybridization and conservation. Biodivers Conserv 18:1435-1439

Giannatos G (2004) Conservation action plan for the golden jackal (Canis aureus L. 1758) in Greece. WWF Greece, Athens

Giannatos G, Marionos Y, Maragou P, Catsadorakis G (2005) The status of the golden jackal (Canis aureus L.) in Greece. Belg J Zool 135:145-149

Grant PR, Grant BR, Petren K (2005) Hybridization in the recent past. Am Nat 166:56-67

Groff C, Bragalanti N, Rizzoli R, Zanghellini P (2014) 2013 bear report with appendices on the lynx, wolf and golden jackal. Forestry and Wildlife Department of the Autonomous Province of Trento, Trento

Heltai M, Ćrović D, Szabó L, Penezić A, Nagyapáti N, Kurys A, Lanszki J (2012) Golden jackal: opinions versus facts. Experiences from Serbia and Hungary. In: Proceedings from the 2nd international symposium on hunting 'modern aspects of sustainable management of game populations', ZemunBelgrade, Serbia, 22-24 June 2012, pp 13-20

Heptner VG, Naumov NP, Yurgenson PB, Sludskii AA, Chirkova AF, Bannikov AG (1998) Mammals of the Soviet Union, vol. 2, part 1a. Sirenia and Carnivora. Smithsonian Institution Libraries and The National Science Foundation, Washington D.C.

Hobbs RJ, Higgs ES, Hall CM (2013) Novel ecosystems: intervening in the new ecological world order. Wiley, Oxford

Humer A (2006) Goldschakale in Österreich: aktueller Status und Managementstrategien unter besonderer Berücksichtigung der Einstellung und des Wissens zum Thema Goldschakal bei österreichischen Bezirksjägermeistern. Diploma thesis. Institute of Wildlife Biology and Game Management, University of Natural Resources and Life Sciences, Vienna 
Jhala YV, Moehlman PD (2004) Golden jackal Canis aureus Linnaeus, 1758. In: Sillero-Zubiri C, Hoffmann M, Macdonald DW (eds) Canids: foxes, wolves, jackals and dogs. status survey and conservation action plan. IUCN/SSC Canid Specialist Group, Gland and Cambridge, Cambridge, pp 156-161

KORA (2012) Erster Goldschakal-Nachweis in der Schweiz. KORA News. http://www.kora.ch/index. php?id=214andL=1 andtx_ttnews\%5Btt_news\%5D=408andcHash=be9f32a37b98a1803257ca8cba134 657. Accessed 13 Jan 2015

Koubek P, Cerveny J (2007) The golden jackal (Canis aureus) - a new mammal species in the Czech Republic. Lynx (Praha) 38:103-106

Krofel M (2008a) Jackals in Slovenia. Lovec 91:10-12 (In Slovenian)

Krofel M (2008b) Survey of golden jackals (Canis aureus) in Northern Dalmatia, Croatia: preliminary results. Natura Croatica 17:259-264

Krofel M (2009) Confirmed presence of territorial groups of golden jackals (Canis aureus) in Slovenia. Natura Sloveniae 11:65-68

Kryštufek B, Tvrtkovič N (1990) Range expansion by Dalmatian jackal population in the twentieth century (Canis aureus L., 1758). Folia Zool 39:291-296

Kryštufek B, Murariu D, Kurtonur C (1997) Present distribution of the golden jackal Canis aureus in the balkans and adjacent regions. Mamm Rev 27:109-114

Lapini L, Molinari P, Dorigo L, Are G, Beraldo P (2009) Reproduction of the golden jackal (Canis aureus moreoticus I. Geoffroy Saint Hilaire, 1835) in Julian pre-Alps, with new data on its range expansion in the high-adriatic hinterland. Bollettinio del Museo Civico di Storia Naturale di Venezia 60:169-186

Lapini L, Conte D, Zupan M, Kozlan L (2011) Italian jackals 1984-2011: an updated review. Bollettinio del Museo Civico di Storia Naturale di Venezia 62:1-20

Leonard JA, Echegaray J, Randi E, Vilà C (2014) Impact of hybridization with domestic dogs on the conservation of wild canids. In: Gompper ME (ed) Free-ranging dogs and wildlife conservation. Oxford University Press, Oxford, pp 170-185

Levickaite R (2015) Lietuvoje sumedžiotas pirmasis šakalas-didžiulès bèdos pranašas. DELFI, The Lithuania Tribune. http://grynas.delfi.lt/gamta/lietuvoje-sumedziotas-pirmasis-sakalas-didziulesbedos-pranasas.d?id=67703144. Accessed 19 June 2015 (In Lithuanian)

Linnell JDC, Boitani L (2012) Building biological realism into wolf management policy: the development of the population approach in Europe. Hystrix Ital J Mamm 23:80-91

Linnell JDC, Salvatori V, Boitani L (2008) Guidelines for population level management plans for large carnivores in Europe. A Large Carnivore Initiative for Europe report prepared for the European Commission (contract 070501/2005/424162/MAR/B2)

López-Precioso B (2012) La protección de las especies de la fauna y flora en la Directiva de Hábitats. In: García Ureta A (ed) La Directiva de Hábitats de la Unión Europea: balance de 20 Años. Editorial Aranzadi, Cizur Menor, pp 69-102

LSM (2014) Golden jackal feels right at home in Latvian woods. LSV news. http://www.lsm.lv/en/article/ societ/society/golden-jackal-feels-right-at-home-in-latvian-woods.a103548/. Accessed 13 Jan 2015

Malez V (1984) The zooarcheological data as the base of colonizing the Markova cave on the island of Hvar. In: 9th Yugoslavian speleological congress, congress proceedings, pp 617-621 (In Croatian, with English summary)

Markov G (2012) Golden Jackal (Canis aureus L.) in Bulgaria: what is going on? Acta Zoologica Bulgarica 64(Suppl. 4):67-71

Mihelič M, Krofel M (2012) New records of the golden jackal (Canis aureus L.) in the upper Soča valley, Slovenia. Natura Sloveniae 14:51-63

Möckel R (2000) Ein Goldschakal (Canis aureus) in Südbrandenburg-Erstnachweis für Deutschland. Säugetierkundliche Informationen 4:477-481

Monzón J, Moyer-Horner L, Palamar MB (2011) Climate change and species range dynamics in protected areas. Bioscience 61:752-761

Moura AE, Tsingarska E, Dąbrowski MJ, Czarnomska SD, Jędrzejewska B, Pilot M (2014) Unregulated hunting and genetic recovery from a severe population decline: the cautionary case of Bulgarian wolves. Conserv Genet 15:405-417

Parmesan C, Yohe G (2003) A globally coherent fingerprint of climate change impacts across natural systems. Nature 421:37-42

Pillai A, Heptinstall D (2013) Twenty years of the Habitats Directive: a case study on species reintroduction, protection and management. Environ Law Rev 15:27-46

Redpath SM, Young J, Evely A, Adams WM, Sutherland WJ, Whitehouse A, Amar A, Lambert RA, Linnell JDC, Watt A, Gutierrez RJ (2013) Understanding and managing conservation conflicts. Trends Ecol Evol 28:100-109 
Rocha-Camarero G, De Trucios SJH (2002) The spread of the collared dove Streptopelia decaocto in Europe: colonization patterns in the west of the Iberian Peninsula. Bird Study 49:11-16

Roženko N, Volokh A (2010) The golden jackal (Canis aureus L., 1758) as a new species in the fauna of Ukraine. Beiträge zur Jagd Wildforschung 35:237-246

Rutledge LY, Patterson BR, Mills KJ, Loveless KM, Murray DL, White BN (2010) Protection from harvesting restores the natural social structure of eastern wolf packs. Biol Conserv 143:332-339

Rutledge LY, White BN, Row JR, Patterson BR (2012) Intense harvesting of eastern wolves facilitated hybridization with coyotes. Ecol Evol 2:19-33

Šálek M, Červinka J, Banea OC, Krofel M, Ćirović D, Selanec I, Penezić A, Grill S, Riegert J (2014) Population densities and habitat use of the golden jackal (Canis aureus) in farmlands across the Balkan Peninsula. Eur J Wildl Res 60:193-200

Selanec I, Lauš B, Sindičić M (2011) Golden jackal (Canis aureus) distribution in Croatia. Abstr Book Eur Mamm Congr 2011:60

Sommer R, Benecke N (2005) Late-Pleistocene and early Holocene history of the canid fauna of Europe (Canidae). Mamm Biol 70:227-241

Spassov N (1989) The position of jackals in the Canis genus and life-history of the golden jackal (Canis aureus L.) in Bulgaria and on the Balkans. Historia Naturalis Bulgarica 1:44-56

Stoyanov S (2012) Golden jackal (Canis aureus) in Bulgaria: Current status, distribution, demography and diet. In: Proceedings from the 2 nd international symposium on hunting 'modern aspects of sustainable management of game population', Zemun-Belgrade, Serbia, 22-24 June 2012, pp 48-56

STV (2012) Žitel’ iz derevni Tomašovka Brestskoj oblasti podstrelil šakala. http://www.ctv.by. Accessed 7 March 2015 (In Russian)

Szabo L, Heltai M, Lanszki J, Szucs E (2007) An indigenous predator, the golden jackal (Canis aureus L., 1758) spreading like an invasive species in Hungary. Bull USAMV-CN 63-64:1-6

Toom M (2014) Šaakali (Canis aureus L.) areaali laienemine Euroopas viimastel aastakümnetel. Jackal range expansion in Europe. BA thesis. Estonian University of Life Sciences, Tartu (In Estonian with English abstract)

Tóth T, Krecsák L, Szücs E, Heltai M, Huszár G (2009) Records of the golden jackal (Canis aureus L., 1758) in Hungary from 1800 until 2007, based on literature survey. North-West J Zool 5:386-405

Trbojević I, Malešević D (2014) Distribution and status of golden jackal Canis aureus in Bosnia and Herzegovina. In: Abstract book, First International Jackal Symposium, Veliko Gradište, Serbia, 13-16 Oct 2014, p 52

Trouwborst A (2010) Managing the carnivore comeback: international and EU species protection law and the return of lynx, wolf and bear to Western Europe. J Environ Law 22:347-372

Trouwborst A (2012) Transboundary wildlife conservation in a changing climate: adaptation of the Bonn Convention on Migratory Species and its daughter instruments to climate change. Diversity 4:258-300

Trouwborst A (2013) Bird conservation and climate change in the marine Arctic and Antarctic: classic and novel international law challenges converging in the polar regions. J Int Wildl Law Policy 16:1-40

Trouwborst A (2014a) Exploring the legal status of wolf-dog hybrids and other dubious animals: international and EU law and the wildlife conservation problem of hybridization with domestic and alien species. Rev Eur Comp Int Environ Law 23:111-124

Trouwborst A (2014b) Living with success-and with wolves: addressing the legal issues raised by the unexpected homecoming of a controversial carnivore. Eur Energy Environ Law Rev 23:89-101

Trouwborst A (2014c) The EU Habitats Directive and wolf conservation and management on the Iberian Peninsula: a legal perspective. Galemys-Spanish. J Mamm 26:15-30

Trouwborst A (2014d) The Habitats Directive and climate change: is the law climate proof? In: Born C, Cliquet A, Schoukens H, Misonne D, Van Hoorick G (eds) The Habitats Directive in its EU environmental law context: European nature's best hope?. Routledge, London, pp 303-324

Trouwborst A (2015a) Law and conservation conflicts. In: Redpath SM, Gutiérrez RJ, Wood KA, Young JC (eds) Conflicts in conservation: navigating towards solutions. Cambridge University Press, Cambridge, pp 108-118

Trouwborst A (2015b) Global large carnivore conservation and international law. Biodivers Conserv 24:1567-1588

Vuletić-Vukasović V (1908) Jackal on Korčula island. Štamparija Degiulli i dr, Dubrovnik (In Croatian)

Weingarth K, Gahbauer M, Heurich M, Muller J, Leibl F (2012) Expertenbestätigter Goldschakal (Canis aureus) im Nationalpark Bayerischer Wald, Deutschland. Säugetierkundliche Informationen 8:443-446

Žila S (2014) Jackal in Ukraine. http://www.hunt-fish.com.ua/article.htm?ident=c3f4fe7219d91b0. Accessed 20 Jan 2015 (In Ukranian) 